chối chi trả tâp trung vào các biến số về kiến thức và thai độ của đối tượng. Chẳng hạn như đối tượng lo lắng mình sẽ mắc UTĐTT và đánh giá bản thân có nguy cơ mắc UTĐTT thấp hơn mọi người có xác suất từ chối chi trả cao hơn. Tuy nhiên, kết quả phân tích cũng cho thấy việc đối tượng lo lắng mình sẽ mắc UTĐTT có xác suất từ chối chi trả cao hơn. Đây là một kết quả tương đối đặc biệt. Tuy nhiên, điều này cũng có thể lý giải được thông qua việc xem xét các lý do trả lời của đối tượng trong nghiên cứu gốc đó là việc từ chối thực hiện sàng lọc do "sợ phát hiện ra bệnh". Kết quả của mô hình phân tích hồi quy logistic đa biến kể trên có thể cung cấp một số bằng chứng khẳng định cho vai trò của các kế hoạch truyền thông trong tương lai. Để cho chương trình sàng loc UTĐTT sử dụng FOBT và nội soi đại trực tràng thực sự có hiệu quả thì việc truyền thông nhằm tăng cường kiển thức và thái độ của đối tượng là vô cùng quan trọng nhẳm tăng cường số lượng đối tượng đích tiếp cận các kỹ thuật sàng lọc.

\section{KẾT LUÂ̂N}

Kiến thức của đối tượng ("không nghĩ mình có bệnh" hay "thiếu hiểu biết thông tin khám sàng lọc", "không biết về phương pháp này có thể sàng lọc được" hay "chỉ khi nào có biểu hiện bệnh thì mới đi khám") là rào cản phổ biến nhất $(43,7 \%)$ trong việc chi trả tiên túi để thực hiện xét nghiệm FOBT. Rào cản phổ biến nhất đối với chi trả tiền để nội soi đại trực tràng liên quan đến sự sợ hãi $(34,8 \%)$ ("sợ hãi khi phát hiện ra bệnh", "sợ đến bệnh viện", "sợ gây mê", "sợ đưa dụng cụ vào cơ thể gây khó chịu" hay "sợ đau"). Kiến thức và thái độ của đối tượng đối với UTĐTT được chỉ ra là có mối liên quan có ý nghĩa thống kê đối với tỷ lệ từ chối chi trả tiền túi để thực hiện sàng lọc UTĐTT. Các can thiệp nhằm cải thiện kiến thức của đối tượng đích đối xét nghiệm FOBT và thay đổi "sự sợ hãi" của đối tượng với với nội soi đại trực tràng là rất quan trọng nhằm cải thiện hiệu quả của các can thiệp sàng lọc UTĐTT trong tương lai.

\section{TÀI LIÊU THAM KHẢO}

1. Nguyễn Thanh Hương and L.N. KHuê, Gánh nặng bệnh tật và tuổi thọ khỏe mạnh: Khái niệm, phương pháp và kết quả của Việt Nam giai đọan 2008-2017. 2019.

2. Nguyễn Thu Hà and Nguyễn Quỳnh Anh, Báo cáo đề tài cấp cơ sở: Đánh giá mức sẵn sàng chi trả đối với mô̂t số can thiêp phát hiên sớm ung thư tại Việt Nam - Nghiên cứu trường hợp đối với Ung thư đại trực tràng. 2020, Trường Đại học $Y$ tế Công cộng: Hà Nội, Việt Nam.

3. Brouse, C.H., et al., Barriers to colorectal cancer screening with fecal occult blood testing in a predominantly minority urban population: a qualitative study. American journal of public health, 2003. 93(8): p. 1268-1271.

4. Javadzade, S.H., et al., Barriers related to fecal occult blood test for colorectal cancer screening in moderate risk individuals. Journal of education and health promotion, 2014. 3.

5. Jones, R.M., et al., Patient-reported barriers to colorectal cancer screening: a mixed-methods analysis. American journal of preventive medicine, 2010. 38(5): p. 508-516.

\title{
THỰC TRANG ĐIỀU KIỆN LAO ĐộNG VÀ SỨC KHỎE CÔNG NHÂN NGÀNH MAY TẠI CÔNG TY TNHH HAIVINA KIM LIÊN, NGHỆ AN NĂM 2020
}

\section{Hoàng Thị Giang1, Lê Tuấn $\mathrm{Anh}^{2}$, Vũ Hải Vinh ${ }^{3}$, Phạm Minh Khuêt}

\section{TÓM TẮT}

Nghiên cứu mô tả cắt ngang tiến hành tại Công ty TNHH Haivina Kim Liên, Nghệ An từ tháng 1 đến tháng 12 năm 2020 dựa trên cổng cụ đo đạc đánh giá

\footnotetext{
1 Trường Đại học Y Dược Hải Phòng

${ }^{2}$ Trung tâm Kiểm soát bệnh tật tỉnh Nghệ An

${ }^{3}$ Bệnh viện Hữu nghị Việt Tiệp, Hải Phòng

Chịu trách nhiệm chính: Hoàng Thị Giang

Email: hoangggiang0708@gmail.com

Ngày nhận bài: 9.3.2021

Ngày phản biên khoa học: 10.5.2021

Ngày duyệt bài: 18.5.2021
}

môi trường lao động và 1000 người lao động thuộc công ty nhằm mục đích đánh giá điều kiện lao động tại và tình trang sức khỏe bệnh tật của công nhân tại cơ sở này. Kết quả nghiên cứu cho thấy, về điều kiện lao động, 20/45 mấu đo nhiệt độ, 21/45 mấu đo độ ẩm, 18/45 mẫu đo tốc độ gió, 26/45 mẫu đo chiếu sáng, 6/45 mẫu đo tiếng ồn và 11/45 mẫu đo bụi bông không đạt tiêu chuẩn cho phép theo các tiêu chuẩn cho phép tại Việt Nam. Tỉ lệ người lao động có sức khỏe loại I, loại II chiếm tỉ lệ cao nhất với 86,9\%. Bệnh tật tai - mũi - họng và phế quản - phổi là những nhóm bệnh tật có tî lệ cao nhất trong cơ cấu bệnh tật của cổng nhân may tại đây, tỉ lệ lần lượt là $15,3 \%$ và $10,6 \%$. Tuổi nghề cao có ành hưởng đển tỉ lệ mắc các bệnh lí tai - mũi - họng, phế quản - phổi, 
thần kinh, mắt, da liễu, phụ khoa. Điều kiện làm việc và tình trạng sức khỏe của công nhân còn nhiều bất cập cần được quan tâm giải quyết.

Tư khoá: công nhân may, điều kiện lao động, cơ cấu bệnh tật, Nghệ An.

\section{SUMMARY \\ WORKING CONDITIONS OF HALOTEXCO GARMENT JOINT STOCK COMPANY, IN NGHE AN IN 2017}

The cross-sectional descriptive study conducted at Haivina Kim Lien Co., Ltd., Nghe An from January to December 2020, is based on a measuring and evaluating the working environment and 1000 employees of the company to evaluate price of working conditions and health status of workers at this facility. Research results show that, for working conditions, 20/45 temperature samples, 21/45 humidity samples, $18 / 45$ wind speed samples, 26/45 lighting measurement samples, 6/45 samples noise measurement and 11/45 cotton dust samples exceed the permitted standards according to the permitted standards in Vietnam. The percentage of workers with health type I, type II accounted for the highest rate with $86,9 \%$. Ear - nose - throat and bronchial - lung diseases were the highest rate in the disease structure of garment workers here, $15.3 \%$ and $10.6 \%$ respectively. The high occupational age affects the rate of ear - nose - throat, bronchial - lung, neurological, eye, dermatological, and gynecological diseases. Working conditions and health status of workers still have many shortcomings that need to be addressed.

Keywords: textile workers, labor conditions, patterns of diseases, Nghe An.

\section{I. ĐĂT VẤN ĐỀ}

Ngành công nghiệp dệt may được coi là một trong những ngành trọng điểm của nhiều nước trên thế giới. Công nghệ dệt may đang có xu hướng chuyển dịch sang các nước đang phát triển, các nước chậm phát triển vì lợi thế về nguồn nhân lực. Sự chuyển dịch của công nghệ dệt may sang các nước nghèo, đầu tư cớ sở hạ tầng, máy lạc hậu sẽ là nguy cơ ô nhiễm môi trường, điều kiện lao động không đảm bảo tại các nước nghèo gia tăng. Ngay tại nước Mỹ, một nước công nghiệp tiến bộ vào loại bậc nhất thế giới, ô nhiễm bụi môi trường lao động và các điêu kiện khác của môi trường lao động cũng vẫn tồn tại nhiều vấn đề [1]. Khi nghiền cứu về môi trường lao động của công nhân dệt may tại các nước châu Á, nhiều tác giả cho rằng vấn đề ô nhiễm bụi hỗn hợp hữu cơ, vô cơ và vi khí hậu bất lợi đang là vấn đề có nguy cơ cao đối với sức khỏe [2]. Cũng từ những nghiên cứu này đã ghi nhận môi trường vi khí hậu bất lợi đang là rất phổ biến góp phần gây hậu quả xấu cho sức khỏe người lao động. Một số nghiên cứu đã chỉ ra rằng điều kiện lao động không tốt, tư thế gò bó gặp trên $60 \%$ người lao động phải chịu đựng trong công nghêe may mặc đang là nguy cơ cao đối với nhiều bệnh ở hệ thống cơ, xương, khớp của công nhân.

Ngành dệt may Việt Nam hiện nay đang được xem là ngành sản xuất có tiềm lực phát triển khá mạnh. Hàng dệt may của chúng ta đã chiếm lĩnh nhiều thị trường may mặc trên thế giới do nhiều ưu thế về nhân lực, có sự tham gia của nhiều thành phần kinh tế khác nhau và kỹ thuật phù hợp. Cũng như trên thế giới, công nghệ dệt may Việt Nam có lịch sử phát triển lâu đời. Dệt may là mặt hàng mũi nhọn của Việt Nam trong chiến lược phát triển kinh tế - xã hội. Ngành may tuy liên tục đầu tư mở rộng sản xuất, đổi mới thiết bị và dây chuyền nhưng cũng chưa đáp ứng được yêu cầu tiêu dùng và xuất khẩu ngày càng tăng. Xuất khẩu hàng dệt may tuy đạt kim ngạch cao, nhưng chủ yếu là làm gia công. Cũng nhu nhiều nước đang phát triển, do đặc điểm ngành nghề, công việc, đặc thù của ngành may ở nước ta là lao động nữ, chiếm khoảng $80-90 \%$ lực lượng sản xuất, thời gian làm việc trung bình thường trên 8giờ/ngày, nhiều khi cống nhân phải làm việc tăng ca tới 10 - 12 giờ/ngày.

Công ty TNHH Haivina Kim Liên, Nghệ An thuộc cụm Công nghiệp Nam Giang, xã Nam Giang, huyện Nam Đàn, tỉnh Nghệ An thành lập vào ngày 26 tháng 3 năm 2012, đây là nhà máy dệt thứ 3 tại thị trường Việt Nam trực thuộc Tập đoàn Hyunjin, chuyên gia công, sản xuất găng tay thể thao, quần áo thể thao và phụ trang trang phục thể thao, với tổng số lao động là sấp xỉ 3200 người, số lao động trực tiếp sản xuất trên 3000 người, đóng góp rất lớn vào việc phát triển kinh tế của địa phương. Nghiên cứu này được thực hiện nhằm mô tả thực trạng điều kiện lao động và sức khỏe công nhẩn ngành may tại công ty TNHH Haivina Kim Liên năm 2020.

\section{II. ĐỐI TƯợNG VÀ PHƯƠNG PHÁP NGHIÊN CỨU}

\section{1 Đối tượng nghiên cứu}

- Điều kiện lao động của Công ty TNHH Haivina Kim Liên, Nghệ An, gồm các yếu tố vi khí hậu, chiếu sáng, tiếng ồn, bụi bông

- Công nhân Công ty TNHH Haivina Kim Liên, Nghệ An: người lao động trực tiếp tại các phân xưởng may quần áo, may găng tay và phân xưởng Insonic, có thời gian làm việc tại công ty ít nhất 2 năm.

1.1. Địa điểm và thời gian nghiên cứu. Nghiên cứu được tiến hành từ tháng 1 năm 2020 đến tháng 10 năm 2020 tại Công ty TNHH 
Haivina Kim Liên, Nghê An.

1.2. Thiết kế nghiên cứu. Thiết kế nghiên cứu mô tả cắt ngang.

2.4. Cõ̃ mẫu nghiên cứu. Cỡ mẫu đánh giá môi trường lao động (MTLĐ): Chọn 45 mẫu đo tại 3 phân xưởng may quần áo, may găng tay và Insonic cho mỗi yếu tố gồm nhiệt độ, độ ẩm, tốc độ gió, bui, ánh sáng, tiếng ồn.

Cỡ mẩu đánh giá thực trạng sức khỏe người lao động: được tính theo công thức tính cỡ mẫu ước lượng tỉ lệ:

$$
n=\frac{Z_{1}^{2}{ }_{12} \cdot p \cdot q}{(d)^{2}}
$$

$Z^{2}$ 1-a/2 hệ số tin cậy với $a=0,5 \%$ độ tin cậy $95 \%$ thì $Z_{1-a / 2}=1,96$

d: khoảng sai lệch cho phép giwuax tỷ lệ thu được từ mẫu nghiên cứu và tî lệ của quần thể, chọn $d=0,03$;

p: Tỷ lệ người lao động mắc các bệnh mũi họng cấp tính trong công nhân ngành may, chọn $\mathrm{p}=0,3$ theo nghiên cứu của Nguyễn Đình Dũng (2012) [3].

Thay vào công thức tính cõ mẫu ta được $n=$ 896. Vậy cỡ mẫu tối thiểu là 896 người, cộng thêm $10 \%$ dự phòng người lao động bỏ cuộc, chúng tôi làm tròn cỡ mẩu là 1000 người.

2.5. Phương pháp chọn mẫu: Chọn ngẫu nhiên phân tầng theo phân xưởng những công nhân có thời gian làm việc từ 02 năm trở lên, tình nguyện tham gia nghiên cứu. Theo số liệu của công ty, 03 phân xưởng có khoảng 3000 công nhân làm việc từ 2 năm trở lên, trong đó phân xưởng may quần áo có 1387 công nhân, phân xưởng may găng có 1.426 công nhân, phân xưởng Insonic có 187 công nhân, chúng tôi tiến hành chọn ngẫu nhiên trong danh sách công nhân làm việc từ 2 năm trở lên từ 3 phân xưởng trên vào nghiên cứu, cụ thể bao gồm 462 công nhân từ phân xưởng may quần áo, 475 công nhân từ phân xưởng may găng tay và 63 công nhân từ phân xưởng Insonic.

2.6. Phương pháp thu thâp thông tin: Các yếu tố MTLĐ được đo bằng các phương tiện đo và đánh giá theo QCVN số 22; Số 24; Số 26 ngày 30/6/2016 của Bộ Y tế và được đo đạc bởi cán bộ y tế thuộc khoa bệnh nghề nghiệp trung tâm kiểm soát bệnh tật tỉnh Nghệ An. Trong điều kiện thời tiết đảm bảo, các mẫu được lấy ngay tại hiện trường, các vị trí đo đã được lựa chọn theo vị trí công việc và theo tiêu chuẩn Việt Nam. Mỗi vị trí lấy mẫu vào các thời điểm khác nhau, đo trực tiếp và lấy giá trị trung bình các lần đo.
- Đo vi khí hậu bằng máy: Extech Instruments (Mỹ). Sản xuất năm: 2009.

- Đo ánh sáng bằng máy: Sper Scientific (Đài Loan - Trung Quốc). Sản xuất năm: 2012.

- Đo tiếng ồn bằng máy: Cirrus Research Plc (Anh). Sản xuất năm: 2012.

- Đo bụi bằng máy: Microdust (Nhật Bản). Sản xuất năm: 2007.

Thu thập thông tin về sức khoẻ: Phỏng vấn trực tiếp đối tượng nghiên cứu các thông tin về cá nhân về một số bệnh tật và điều kiện trong môi trường làm việc bằng bộ câu hỏi (phiếu điều tra) thiết kế sẵn. Thu thập thông tin sức khỏe qua kết quả khám sức khỏe, khám phát hiện bệnh nghề nghiệp tháng 5, 6, 7, 8 năm 2020 do các y bác sỹ nhiều chuyên khoa thuộc trung tâm kiểm soát bệnh tật tỉnh Nghê An.

Phân loại sức khỏe người lao động theo "Tiêu chuẩn phân loại sức khỏe để khám tuyển, khám định kỳ đối với học sinh các trường đại học, trung học chuyên nghiệp, trường dạy nghề và lao động các nghề, công việc" do Bộ Y tế ban hành kèm theo quyết định số 1613/QĐ- BYT ngày 15/08/1997 của Bộ trưởng Bộ $Y$ tế. Phân loai bệnh tật: theo phân loại của tổ chức $Y$ tế thế giới (ICD-10) để xác định cơ cấu bệnh tật của người lao động.

2.7. Xử lí và phân tích số liêu: Số liêu được nhâp và phân tích số liêu được tiến hành bằng phần mềm SPSS.22.0. Các số liệu được trình bày dưới dạng giá trị trung bình, tỉ lệ. Các test thống kê sử dụng bao gồm Khi bình phương để so sánh tỉ lệ, ngưỡng giá trị thống kê khi p> 0,05.

2.8. Đạo đức nghiên cứu: Nghiên cứu được triển khai sau khi đã báo cáo và được sự đồng thuân về nội dung nghiên cứu với Lãnh đạo doanh nghiệp có liên quan, được các cơ quan cho phép. Đối tượng nghiên cứu tự nguyện tham gia sau khi đã được giải thích rõ về mục đích và ý nghĩa của nghiên cứu. Thông tin thu thập trung thực, khách quan, được bảo mật và chỉ sử dụng cho mục đích nghiên cứu.

\section{KẾT QUẢ NGHIÊN CứU}

\subsection{Thực trạng điêu kiện lao động của} công ty Haivina Kim Liên, Nghệ An

Nhiệt độ môi trường lao động không đạt tiêu chuẩn vệ sinh cho phép chiếm tỷ lệ $44,45 \%$. Các mẫu đo về độ ẩm môi trường lao động không đạt tiêu chuẩn vệ sinh cho phép (TCVSCP) chiếm tỷ lệ $46,67 \%$ và tốc độ gió trong môi trường lao động không đạt tiêu chuẩn cho phép chiếm tỷ lệ 40,0\% (Bảng 1). 
Bảng 1. Đặc điểm vi khí hậu tại nơi làm việc

\begin{tabular}{|c|c|c|c|c|c|c|}
\hline \multirow[b]{3}{*}{ Địa điểm } & \multicolumn{6}{|c|}{ Chỉ tiêu vi khí hậu } \\
\hline & \multicolumn{2}{|c|}{ Nhiệt độ ( $\left.{ }^{\circ} \mathrm{C}\right)$} & \multicolumn{2}{|c|}{ Độ̂ấm (\%) } & \multicolumn{2}{|c|}{ Tốc độ gió (m/s) } \\
\hline & $\begin{array}{c}\text { Số mấu } \\
\text { không } \\
\text { đạt }\end{array}$ & $\begin{array}{l}\text { Tỉ lệ mầu } \\
\text { không đạt } \\
\text { TCCP }\end{array}$ & $\begin{array}{c}\text { Số mâu } \\
\text { không } \\
\text { đat }\end{array}$ & $\begin{array}{c}\text { Tỉ lệ mầu } \\
\text { không đạt } \\
\text { TCCP }\end{array}$ & $\begin{array}{c}\text { Số mâu } \\
\text { không } \\
\text { đat }\end{array}$ & $\begin{array}{l}\text { Tỉ lệ mấu } \\
\text { không đạt } \\
\text { TCCP }\end{array}$ \\
\hline Phân xưởng Insonic $(n=09)$ & 05 & 55,56 & 03 & 33,34 & 03 & 33,34 \\
\hline $\begin{array}{c}\text { Phân xướng may quần } \\
\text { áo }(\mathrm{n}=18)\end{array}$ & 10 & 55,56 & 11 & 61,12 & 06 & 33,34 \\
\hline Phân xưởng may găng tay & 05 & 27,78 & 07 & 38,89 & 09 & 50,00 \\
\hline Tống số $(n=45)$ & 20 & 44,45 & 21 & 46,67 & 18 & 40,00 \\
\hline $\begin{array}{l}\text { TCVSCP theo QCVN } \\
26: 2016 / \mathrm{BYT}\end{array}$ & \multicolumn{2}{|c|}{$20-34^{\circ} \mathrm{C}$} & \multicolumn{2}{|c|}{$40-80 \%$} & \multicolumn{2}{|c|}{$0,1-1,5 \mathrm{~m} / \mathrm{s}$} \\
\hline
\end{tabular}

Về các chỉ tiêu ánh sáng, tiếng ồn và nồng độ bụi bông, tỉ lệ không đạt về chiếu sáng chiếm cao nhất (57,78\%), sau đó đến bụi bông $(24,44 \%)$ và tiếng ồn (13,33\%) (Bảng 2$)$.

Bảng 2. Đặc điểm ánh sáng, tiếng ồn, nồng độ bụi bông tại nơi làm việc $(n=45)$

\begin{tabular}{|c|c|c|c|c|c|c|}
\hline \multirow[b]{2}{*}{ Địa điểm } & \multicolumn{2}{|c|}{ Chỉ tiêu ánh sáng } & \multicolumn{2}{|c|}{ Chỉ tiêu tiếng ôn } & \multicolumn{2}{|c|}{ Bụi bông $\left(\mathrm{mg} / \mathrm{m}^{3}\right)$} \\
\hline & $\begin{array}{l}\text { Số mẫu } \\
\text { không đạt }\end{array}$ & $\begin{array}{l}\text { Tỉ lệ mâu } \\
\text { không đạt } \\
\text { TCCP }\end{array}$ & $\begin{array}{l}\text { Số mâu } \\
\text { không } \\
\text { đat }\end{array}$ & $\begin{array}{l}\text { Tỉ lệ mâu } \\
\text { không đạt } \\
\text { TCCP }\end{array}$ & $\begin{array}{c}\text { Số mâu } \\
\text { không } \\
\text { đat }\end{array}$ & $\begin{array}{l}\text { Tỉ lệ mâu } \\
\text { không đạt } \\
\text { TCCP }\end{array}$ \\
\hline $\begin{array}{c}\text { Phân xưởng Insonic } \\
(\mathrm{n}=09)\end{array}$ & 03 & 33,33 & 02 & 22,22 & 02 & 22,22 \\
\hline $\begin{array}{l}\text { Phân xườn } \\
\text { quần áo ( }\end{array}$ & 12 & 66,67 & 03 & 16,66 & 05 & 27,77 \\
\hline $\begin{array}{l}\text { Phân xưởng may } \\
\text { qăng tay }(n=18)\end{array}$ & 11 & 61,0 & 01 & 5,55 & 04 & 22,22 \\
\hline Tốn & 26 & 57,78 & 06 & 13,33 & 11 & 24,44 \\
\hline CP & \multicolumn{2}{|c|}{$\begin{array}{c}\text { QCVN 22:2016/BYT } \\
\text { - Tố may } \geq 500 \text { lux } \\
\text { - Bộ phận côn lại } \geq 300 \text { lux }\end{array}$} & \multicolumn{2}{|c|}{$\begin{array}{c}\text { QCVN 24:2016/BYT } \\
\text { S85dBA trung bình } 8 \mathrm{~h} \\
\text { làm việc }\end{array}$} & \multicolumn{2}{|c|}{$\begin{array}{c}\text { QCVN 02:2019/BYT } \\
\leq 1\left(\mathrm{mg} / \mathrm{m}^{3}\right)\end{array}$} \\
\hline
\end{tabular}

3.2. Sức khỏe và bênh tật của công nhân công ty TNHH Hainiva Kim Liên, Nghệ An. Trong số 1000 công nhân tham gia nghiên cứu, tỉ lệ công nhân nữ chiếm 95,6\%, tuổi đời chủ yếu là từ 30 đến 39 (chiếm $53,9 \%$ ) và tuổi nghề chủ yếu là từ 2 đến 7 năm (chiếm 68,4\%).

Kết quả khám và phân loại sức khỏe công nhân may Havina cho thấy tỷ lệ công nhân may có sức khỏe tốt. Công nhân có sức khỏe loại I \&
II (chiếm $86,9 \%$ ), tỷ lê công nhân may có sức khỏe kém (loại IV và V) chiếm $1,3 \%$. Tỉ lệ sức khỏe loại I nam 45,45\% cao hơn nữ $29,91 \%$, không có nam công nhân nào có sức khỏe loại IV và loại V. Nhóm người lao động trên 5 năm tuổi nghề, tỷ lệ sức khỏe loại I giảm, xuất hiện sức khỏe loại IV, V (2.14\%). Phân xưởng may quần áo có tỉ lệ sức khỏe loại IV, $\mathrm{V}$ cao nhất so với 2 phân xưởng còn lại, chiếm 2,38\% (Bảng 3).

Bảng 3. Phân loại sức khỏe của công nhân theo giới, tuổi nghề và vị trí làm việc $(n=1000)$

\begin{tabular}{|c|c|c|c|c|c|}
\hline & & $\begin{array}{c}\text { Loại I SL } \\
(\%)\end{array}$ & $\begin{array}{l}\text { Loại II } \\
\text { SL (\%) }\end{array}$ & $\begin{array}{l}\text { Loại III } \\
\text { SL }(\%)\end{array}$ & $\begin{array}{c}\text { Loại IV, V } \\
\text { sí (\%) }\end{array}$ \\
\hline \multirow[b]{2}{*}{ Giới } & $\operatorname{Nam}(n=44)$ & $20(45,45)$ & $19(43,18)$ & $5(11,36)$ & $0(0)$ \\
\hline & Nữ $(n=956)$ & $286(29,91)$ & $544(56,90)$ & $113(11,82)$ & $13(1,4)$ \\
\hline \multirow{4}{*}{$\begin{array}{l}\text { Tuổi } \\
\text { nghề }\end{array}$} & $2-<3$ năm $(n=200)$ & $68(34)$ & $113(56,5)$ & $18(9,0)$ & $1(0,5)$ \\
\hline & $3-<5$ năm $(n=178)$ & $55(30,89)$ & $106(59,55)$ & $15(8,42)$ & $2(1,12)$ \\
\hline & $5-<7$ năm $(\mathrm{n}=296)$ & $86(29,05)$ & $162(54,72)$ & $45(15,20)$ & $3(1,01)$ \\
\hline & $>7$ năm $(n=326)$ & $97(29,75)$ & $182(55,82)$ & $40(12,26)$ & $7(2,14)$ \\
\hline \multirow{3}{*}{$\begin{array}{l}\text { Vị trí } \\
\text { làm việc }\end{array}$} & May quần áo $(n=462)$ & $141(30,51)$ & $262(56,70)$ & $48(10,38)$ & $11(2,38)$ \\
\hline & May găng tay $(n=475)$ & $146(30,73)$ & $265(55,78)$ & $62(13,05)$ & $2(0,42)$ \\
\hline & Insonic $(n=63)$ & $19(30,15)$ & $36(57,14)$ & $8(12,69)$ & 0 \\
\hline Tổng & & $306(30,6)$ & $563(56,3)$ & $118(11,8)$ & $13(1,35)$ \\
\hline
\end{tabular}


Tỉ lệ công nhân mắc các bệnh mũi họng và phế quản phổi chiếm cao nhất trong cơ cấu bệnh tật. Theo nhóm tuổi nghề, tỉ lệ mắc các bệnh ở mũi họng, phễ quản-phổi, bệnh cơ xương khớp, thần kinh, mắt và bệnh phụ khoa có xu hướng cao nhất ở nhóm công nhân có tuổi nghề $>7$ năm, với sự khác biệt có ý nghĩa thống kê $(p<0,05)$ (Bảng 4).

\section{Bảng 4. Cơ cấu bệnh tật của công nhân theo tuổi nghề}

\begin{tabular}{|c|c|c|c|c|c|}
\hline Tuối nghề & 2 - 3 năm & 3-5 năm & 5 - 7 năm & > 7 năm & Giá trị p \\
\hline Chứng, bệnh & n (\%) & n (\%) & n (\%) & n (\%) & Ga tr! p \\
\hline Bệnh ở mũi, họng & $23(2,3)$ & $28(2,8)$ & $26(2,6)$ & $76(7,6)$ & $p<0,05$ \\
\hline Bệnh ở phế quản, phối & $8(0,8)$ & $12(1,2)$ & $19(1,9)$ & $77(7,7)$ & $p<0,05$ \\
\hline Bênh cơ - xương - khớp & $10(1,0)$ & $7(0,7)$ & $5(0,5)$ & $44(4,4)$ & $p<0,05$ \\
\hline Bệnh tim mạch & $24(2,4)$ & $14(1,4)$ & $14(1,4)$ & $51(5,1)$ & $p>0,05$ \\
\hline Bệnh ngoài da & $9(0,9)$ & $5(0,5)$ & $8(0,8)$ & $21(2,1)$ & $p>0,05$ \\
\hline Bệnh tiều hóa & $6(0,6)$ & $6(0,6)$ & $6(0,6)$ & $18(1,8)$ & $p>0,05$ \\
\hline Bềnh thần kinh & $3(0,3)$ & $2(0,2)$ & $6(0,6)$ & $4(0,4)$ & $p<0,05$ \\
\hline Bệnh về măt & $23(2,3)$ & $17(1,7)$ & $18(1,8)$ & $55(5,5)$ & $p<0,05$ \\
\hline Bềnh phụ khoa & $29(2,9)$ & $14(1,4)$ & $10(1,0)$ & $32(3,2)$ & $p<0,05$ \\
\hline Bệnh RHM & $6(0,6)$ & $8(0,8)$ & $9(0,9)$ & $29(2,9)$ & $p>0,05$ \\
\hline
\end{tabular}

Tỷ lệ bệnh lý mũi họng của người lao động ở phân xưởng may quần áo và găng tay chiếm tỷ lệ cao nhất, tỉ lệ lần lượt là 6,5\% và 7,6\%. Ớ phân xưởng Insonic, tỉ lệ bệnh phế quản phổi chiếm cao nhất với $2,0 \%$. Có sự khác biệt về tỉ lệ bệnh cơ-xương-khớp giữa 3 phân xưởng, tỉ lệ cao nhất ở phân xưởng may găng tay $(4,2 \%)$ với $p<0,05$.

Bảng 5. Cơ câu bệnh tật cưa công nhân theo vị trí việc làm

\begin{tabular}{|c|c|c|c|c|}
\hline Tuối nghề & $\begin{array}{l}\text { Phân xưởng } \\
\text { may quân áo }\end{array}$ & $\begin{array}{l}\text { Phân xưởng } \\
\text { may găng tay }\end{array}$ & $\begin{array}{c}\text { Phân xưởng } \\
\text { Insonic }\end{array}$ & Giá trị $\mathbf{p}$ \\
\hline Chứng, bệnh & n(\%) & n(\%) & n (\%) & \\
\hline Bệnh ở mũi, họng & $65(6,5)$ & $76(7,6)$ & $12(1,2)$ & $p>0,05$ \\
\hline Bệnh ở phế quản, phối & $39(3,9)$ & $57(5,7)$ & $20(2,0)$ & $p>0,05$ \\
\hline Bệnh cơ - xương - khớp & $9(0,9)$ & $42(4,2)$ & $16(1,6)$ & $p<0,05$ \\
\hline Bệnh tim mạch & $55(5,5)$ & $43(4,3)$ & $5(0,5)$ & $p>0,05$ \\
\hline Bệnh ngoài da & $13(1,3)$ & $26(2,6)$ & $4(0,4)$ & $p>0,05$ \\
\hline Bệnh tiều hóa & $12(1,2)$ & $20(2,0)$ & $4(0,4)$ & $p>0,05$ \\
\hline Bệnh thần kinh & $6(0,6)$ & $8(0,8)$ & $1(0,1)$ & $p>0,05$ \\
\hline Bệnh về mắt & $61(6,1)$ & $46(4,6)$ & $6(0,6)$ & $p>0,05$ \\
\hline Bệnh phụ khoa & $41(4,1)$ & $43(4,3)$ & $2(0,2)$ & $p>0,05$ \\
\hline Bệnh RHM & $17(1,7)$ & $32(3,2)$ & $3(0,3)$ & $p>0,05$ \\
\hline
\end{tabular}

\section{BÀN LUẬN}

4.1. Điêu kiện lao động của công nhân may công ty Haivina Kim Liên, Nghệ An

Các số liêuu nghiên cứu thu được về môi trường lao động của 3 phân xưởng tại công ty nhìn chung có nhiều bất cập, có thể ảnh hưởng xấu đến sức khỏe của công nhân. Kết quả từ bảng 1 cho thấy tỷ lệ mẫu có các chỉ tiêu vi khí hậu không đạt đều chiếm đến gần một nửa. Cụ thể, chỉ tiêu nhiệt độ môi trường lao động không đạt TCVSCP là $44,45 \%$, trong đó tại phân xưởng may quần áo và phân xưởng Insonic đều có $55,56 \%$ vượt TCVSCP, phân xưởng may găng tay có $5 / 18$ mẫu $(27,78 \%)$ vượt TCVSCP. Nhiệt độ không khí cao là điều kiện làm cho các yếu tố ô nhiễm khác tác động mạnh hơn. Do vâyy, làm việc trong môi trường nóng sẽ làm cơ thể nhanh mệt mỏi, hệ hô hấp và tim mạch phải tăng cường hoạt động để tăng thải nhiệt. Đối với những công nhân làm việc trong MTLĐĐ có nồng độ bụi cao, việc tăng thồng khí dẫn đến lượng bụi hít vào nhiều hơn, dễ dấn đến các bệnh bụi phổi và bênh lý đường hô hấp. Nhiệt độ tắng cao làm tăng bài tiết mồ hôi, ngoài mất nước và điện giải còn làm cho bụi dễ bám vào da, cản trở quá trình thải nhiêt và dễ mắc các bệnh ngoài da. Đây là vấn đề đặc biệt trong công tác bảo vệ sức khỏe người lao động đã được rất nhiều tác giả quan tâm do nhiều tác động xấu có thể xẩy ra do quá trình điều nhiệt của cơ thể phải đáp ứng vượt giới hạn, gây nển tình trạng mệt mỏi cho người lao động tại doanh nghiệp. Về chỉ tiêu độ ẩm, tỉ lệ số mẫu không đạt cao nhất là phân xưởng may quần áo $(61 \%)$, sau đó đến phân xưởng Insonic và phân xưởng may găng tay. Độ ẩm cao đóng vai trò quan trong cùng với nhiệt độ và độ ẩm gây nên các rối loạn mất cân bằng 
nhiệt cho người lao động. Ngoài ra, đây cũng là môi trường giúp nấm mốc phát triển gây ô nhiễm môi trường, làm cho con người sống làm việc ở đó dễ mắc các bệnh ngoài da. Thực trạng này sẽ ảnh hưởng không tốt đến sức khỏe công nhân vì cả hai trạng thái độ ẩm cao hoặc độ ẩm thấp đều cản trở quá trình điều nhiêtt của cợ thể. Các tác động này sẽ làm cho da khô, hoặc ẩm, dễ cảm nhiễm với các tác nhân gây bệnh trên da [1]. Về chỉ tiêu tốc độ gió, phân xưởng may găng tay lại có tỉ lệ số mấu không đạt TCVSCP cao nhất với $50 \%$. Tốc độ cao gió giúp tăng cường quá trình thải nhiệt qua con đường đối lưu, đồng thời giảm lượng bụi tồn lưu trong không khí. Khi nhắc tới nhiệt độ, không thể không tính đến các yếu tố độ ẩm tương đối và tốc độ gió. Cả ba yếu tố này của vi khí hậu có mối liên hệ qua lại với nhau. Chúng ta đều biết, gió có vai trò khuyếch tán bụi trong môi trường và tham gia điều hòa thân nhiệt nên dù cao quá hay thấp quá đều không tốt. Kết quả nghiên cứu của một số tác giả trong nước ở một số ngành nghề trong thời gian gần đây cho thấy tỷ lệ không đạt TCVSCP nói chung đều khoảng trên dưới 30\% các mẫu đo [4].

Song song với các yếu tố vi khí hậu, chiếu sáng cũng là một yếu tố cần phải cải thiện tại công ty này. Cụ thể, kết quả từ bảng 2 cho thấy có đên gần $60 \%$ số mẫu chưa đạt TCVSCP, khá tương đồng tại cả ba phân xưởng. Chiếu sáng không đầy đủ có thể có liên quan, ảnh hưởng đến các rối loạn bệnh lý ở mắt, gia tăng mệt mỏi, mất an toàn đối với người lao động tại các cơ sở may mặc. Tác động của chiếu sáng chưa tốt cũng cần được quan tâm, nghiên cứu thêm về ảnh hưởng kết hợp với các yếu tố khác của môi trường và điều kiện lao động.

Tiếng ồn môi trường lao động dệt may tuy không quá cao và nguy hiểm như nhiều ngành công nghiệp đặc thù khác, song cũng được xếp vào nhóm có cường độ tiếng ồn cao và có thể gây tác động xấu đến sức khỏe người lao động. Tác hại của tiếng ồn trong công nghệ dệt may gây rối loạn sinh lý, gây mệt mỏi và làm gia tăng tỳ lệ nhiều bệnh đã được các tác giả Nga, Anh, Pháp nghiên cứu từ thế kỷ 19 . Theo nhiều tác giả, tỷ lệ các rối loạn bệnh lý khác do tiếng ồn còn nhiều hơn là gầy ảnh hưởng đến sức nghe [1]. Qua các kết quả nghiên cứu tại Bảng 2 cho thấy tiếng ồn môi trường lao động không đạt TCVSCP cũng còn đáng quan tâm với $22,22 \%$. Kết quả nghiên cứu của chúng tôi cũng tương tự như nghiên cứu của Nguyễn Đức Trọng (2005), môi trường lao động của công nhân giầy Phú Hà cũng có tỷ lệ mẫu đo tiếng ồn không đạt tiêu chuẩn vệ sinh cho phép khoảng $19-25 \%$. Tác giả cũng lưu ý về công tác chăm sóc dự phòng các bệnh nghề nghiệp do tiếng ồn như giảm sức nghe của người lao động [5].

Bụi môi trường lao động là yếu tố căn nguyên của nhiều rối loạn bệnh lý nghề nghiệp. Bụi sinh ra do công nghệ dệt may hiện nay là bụi hỗn hợp, mang thuộc tính hữu cớ cao. Do đặc thù của công nghệ may mặc, bụi thường sinh ra nhiều và dễ phát tán. Khi nghiên cứu về môi trường lao động cũng như các bệnh liên quan, nghề nghiệp, yếu tố bụi luôn được nhiều tác giả coi là một chỉ số quan trọng. Tại công ty Haivina Kim Liên, tổng số mẫu đo bụi không đạt TCVSCP khá cao $(24,45 \%)$. Nếu so sánh với kết quả nghiên cứu về hàm lượng bụi môi trường lao động tại một số cơ sở may ở Hà Nội của Nguyễn Đình Dũng [6], năm 2005, thì số mẫu vượt TCCP thấp hơn nhiều (7,1\%). Như vậy các tác hại do yếu tố nguy cơ này ở công ty Havina là cao hơn và khó có thể cải thiện hơn. Điều này cho thấy công tác chăm sóc và đảm bảo sức khỏe người lao động sẽ còn gặp nhiều khó khăn.

4.2. Sức khỏe và cơ cấu bệnh tật của công nhân công ty TNHH Haivina Kim Liên

Kết quả từ Bảng 3 cho thây tình trạng sức khỏe của công nhân là khá tốt với tỷ lệ công nhân may có sức khỏe tốt (loại I và II) chiếm đến $86,9 \%$. Tỷ lệ người lao động tại công ty có sức khỏe loại II cao nhất, chiếm $56,3 \%$, trong đó nữ giới có sức khỏe loại II $(56,9 \%)$ cao hơn nam (43,3\%). Tỷ lệ người lao động có sức khỏe loại III chiếm tỷ lệ thấp, chỉ có $11,8 \%$. Không có người lao động nam giới nào có sức khỏe loại IV, V, tỷ lệ loại này ở nữ giới cũng chỉ chiếm 1,3\%. Nghiên cứu của Hoàng Thị Thúy Hà [7], năm 2015, thực trạng môi trường, sức khỏe, bệnh tật ở công nhẩn may Thái Nguyên thì tỷ lệ sức khỏe loại I \& II khoảng $80-85 \%$. Theo các kết quả nghiên cứu của đa số các tác giả trong nước, tỷ lệ người lao động có sức khỏe kém ở nước ta (loại IV và V) thường dao động xung quanh 1,5 - 2,8\%.

Tuy nhiên, kết quả cũng cho thấy phân loại sức khỏe có xu hướng giảm đi theo tuổi nghề. Trong đó, tỷ lệ sức khỏe loại I ở nhóm tuổi nghề 2-3 năm là cao nhất (34\%), sau đó giảm dần ở các nhóm tuổi nghề từ 3-5 năm, 5-7 năm. Sức khỏe loại IV, $V$ chủ yếu gặp ở nhóm tuổi nghề trên 7 năm $(2,14 \%)$. Theo vị trí làm việc, tî lệ công nhân có sức khỏe loại IV, $V$ cũng cao hơn ở phân xưởng may quần áo và găng tay. Điều này là khá phù hợp khi mà kết quả quan trắc môi trường đều cho thấy hầu hết các chỉ tiêu ở phân 
xưởng Insonic đạt TCVSCP đều cao hơn so với hai phân xưởng còn lại.

Về cơ cấu bệnh tật của công nhân theo ICD10, nhóm bệnh ở mũi họng chiếm tỷ lệ cao nhất $15,3 \%$, tiếp theo là nhóm bênh ở phế quản phổi $11,6 \%$, nhóm bệnh mắt chiếm $11,3 \%$. Các nhóm bệnh tim mạch huyết áp (10,3\%), bệnh phụ khoa $(8,6 \%)$, bệnh cơ xương khớp $(6,7 \%)$, bệnh răng hàm mặt $(5,2 \%)$, bệnh ngoài da $(4,3 \%)$, bệnh tiêu hóa $(3,6 \%)$, bệnh thân kinh $(1,5 \%)$. Có thể nói các yếu tố độc hại của môi trường như độ ẩm, tiếng ồn, thiếu ánh sáng, bụi ảnh hưởng nhiều tới sức khỏe dẫn đến các bênh lý về tai mũi họng, các bệnh ở phế quản phổi mắt, cao hơn so với các bệnh lý khác. So sánh với kết quả nghiên cứu của các tác giả thuộc tập đoàn dệt may vào các thời điểm tương ứng với nghiên cứu của chúng tôi, thì kết quả về tỷ lệ mắc các bệnh mũi họng của chúng tôi thấp hơn so với họ. Cũng như các bệnh mũi họng, tỷ lệ mắc bênh viêm phế quản được chúng tôi ghi nhận cũng tương đối cao, tới $11,6 \%$. Viêm phế quản là một trong những bệnh có liên quan nhiều đến ảnh hưởng của ô nhiễm bụi hữu cơ tại môi trường lao động và gây tổn hại nhiều đển chức năng hô hấp. Giai đoạn muộn của viêm phế quản và bệnh bụi phổi bồng thường khó phân biệt hoặc viêm phế quản là yếu tố dẫn đường cho bệnh bụi phổi bông đã được một số tác giả khuyến cáo [9]. Trong nghiên cứu của chúng tôi hiện chưa phát hiện trường hợp bị bệnh bựi phổi bồng nghề nghiệp.

Kết quả từ bảng 4 cũng cho thấy tuổi nghề có phần ảnh hưởng đến tî lệ mắc một số chứng bệnh của công nhân tại công ty Haivina Kim Liên, bao gồm bệnh mũi họng, phế quản - phổi, bệnh cơ xương khớp, thần kinh, mắt, da liểu và phụ khoa, khi tuổi nghề tăng thì tỉ lệ mắc các bệnh này đều tăng $(p<0,05)$. Trong khi tại bảng 5 , chúng tôi lại không ghi nhận sự khác biệt về tỉ lế mắc các chứng bênh theo vị trí làm việc, măc dù điều kiện môi trường làm việc là có sự khác nhau giữa các phân xưởng. Chúng tôi cũng phân tích sư khác biệt giữa các nhóm công nhân tại các phân xưởng có các chỉ tiêu môi trường vượt tiêu chuẩn cho phép với nhóm tại các vị trí không vượt tiêu chuẩn, tuy nhiên cũng không ghi nhận sự khác biệt. Điều này một lần nữa cho thấy môi trường lao động có ảnh hưởng rõ rệt đến sức khỏe người lao động, ngay cả khi các yếu tố tác hại nghề nghiệp được kiểm soát. Vì vậy, việc dự phòng và bảo vể sức khỏe cho người lao động cân được thực hiên ngay từ khi công nhân mới bắt đâu vào làm việc là vô cùng cần thiết.

\section{KẾT LUẬN VÀ KHUYẾN NGH!}

Thực trạng điều kiện lao động tại công ty TNHH Haivina Kim Liên, Nghê An còn nhiều bất cập. Các chỉ tiêu vi khí hậu, chiếu sáng, tiếng ồn và bụi bông đều có mẫu chưa đạt tiêu chuẩn cho phép. Tỉ lệ công nhân có sức khỏe loại I và II chiếm chủ yếu, tuy nhiên vẫn còn có cồng nhân có sức khỏe loại III, IV và V. Bệnh tai mũi họng và bệnh phế quản phổi là nhóm bệnh tật chiếm tỉ lệ cao trong cơ cấu bệnh tật của công nhân. Tuổi nghề là yếu tố ảnh hưởng đến tình trạng bệnh tật của công nhân. Công ty cần có chiến lược can thiệp dự phòng và nâng cao sức khỏe cho công nhân.

\section{TÀI LIÊU THAM KHẢO}

1. Barry S. Levy, David H. Wegman, et al. (2011), "Occupational and environmental health recognizing and preventing disease and injury" (6th ed), New York: Oxford University Press, pp. 416-452.

2. Brooks S. M, Bernstein I. L. (2011), "Irritantinduced airway disorders", Immunol. Allergy Clin.

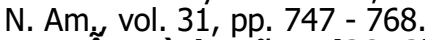

3. Nguyền Đình 'Dũng (2012), "Nghiên cứu điều kiện lao động và nguy cơ gây căng thẳng nghề nghiệp tại một số doanh nghiệp may thuộc tâp đoàn dêt may Viêt Nam", Báo cáo khoa hoc toàn văn, Hội nghị khoa học Quốc tế lần thứ IV về $Y$ học lao động và vệ sinh môi trường, Tạp chí Y học thực hành, Số 849 +850, tr. 109-112.

4. Mài Thi Thu Thảo (2014), "Nghiên cứu đánh giá nguy cở ảnh hưởng tới sức khỏe người lao động tiếp xúc với hơi khí độc trong một số ngành nghề", Tap chí Bảo hộ lao động Số 237, tr. 15 - 21.

5. Nguyễn Đức Trọng (2005), "Nghiên cứu ảnh hưởng của môi trường lao động tới cơ cấu bênh tật của nữ công nhân phân xưởng sách-Công ty in cồng đoàn", Báo cáo khoa học toàn văn, Hội nghị Y hoc lao động toàn quốc lần thứ VI, Nxb Y học, Hà Nội, tr. 489-493.

6. Nguyến Đình Dũ̃ng (2005), "Tình hình mắc bệnh bụi phổi bông ớ công nhân tiếp xúc với bụi bống tại một số công ty sản xuất sợi thuộc Tổng Công ty dệt may Việt Nam", Báo cáo khoa học toàn văn, Báo cáo Hội nghị Y học lao động toàn quốc lần thứ VI, Nxb Y họ, Hà Nối, tr. 356́-361.

7. Hoàng Thị Thúy Hà (2015), "Thực trạng môi trường, sức khỏe, bênh tât ở cống nhân may Thái Nguyên và hiệu quả một số giải pháp can thiệp", Luận văn tiến sĩ Đại học Y - Dược Thái Nguyên.

8. Nguyễn Đình Dũ̃ng (2003), "Đánh giá gánh nậng lao động ở công nhân là hơi của các công ty may", Báo cáo khoa học toàn văn - Hội nghi khoa học y học lao động toàn quốc lần thứ $\mathrm{V}, \mathrm{Nxb} \mathrm{Y}$ hoc, Hà Nội, tr. 204-213.

9. Nguyễn Thị Bích Liền, Nguyễn Đình Dũng (2003), "Nghiên cứu thực trạng gánh năng lao động của công nhân là hới Công ty may Đức Giang - Gia Lâm - Hà Nội", Tạp chí Y học thực hành, Số 1 , tr. $36-39$. 